\title{
Konflik Sosial Masyarakat dengan Perusahaan Sawit Kecamatan Batu Ampar Kabupaten Kubu Raya
}

\author{
Endang Periady ${ }^{1}$, Fatmawati $^{2}$, Pabali Musa ${ }^{3}$ \\ 1. Program Magister Ilmu Sosial Untan \\ 2,3. . Fisip Universitas Tanjungpura
}

Korespondensi Penulis Utama: endangperiady@gmail.com

\begin{abstract}
The research is related to the problem of Social Conflict between the Community and Palm Oil Company in Batu Ampar Sub-district, Kubu Raya Regency. The problem is why social tension occurs between the oil palm plantation company and the local community in Batu Ampar Sub-district. The theory used by Marx aims to describe the social conflict between the community and the owner of palm oil plantation company. The method used is descriptive research that aims to explain intensively about the research in question. It includes the background of the current situation, and the environmental interaction of a social unit: individuals, groups, institutions, or communities. The conclusion from the findings of this research about social conflict between PT. Fajar Saudara Lestari Oil Palm Plantation and the community of Batu Ampar Villages, Batu AMpar Sub-District, Kubu Raya Regency is expected to provide input to various parties. Social conflict between PT. Fajar Saudara Lestari Oil Palm Plantation and the community is due to changes in the socio-economic structure of the community from the capacity system through patterns for business. As a result of the entry o the oil palm plantation, there is a grouping of people over the structure of resources, including: groups that have the power of economic resources and groups that have social resources.
\end{abstract}

Key words : Social conflict, Oil Palm Plantation Farmers, Batu Ampar-Kubu Raya 


\section{PENDAHULUAN}

Masyarakat Kalimantan Barat yang resisten terhadap ekspansi perkebunan kelapa sawit, khususnya Desa Batu Ampar Kecamatan Batu Ampar Kabupaten Kubu Raya telah mengarah pada sejumlah konflik, dan konflik tersebut penelitian awal ekspansi perkebunan kelapa sawit telah terjadi di areal hutan sebagai tanah adat yang sebelumnya ditempati masyarakat, pembebasan lahan; dan desakan kebutuhan sosial ekonomi masyarakat, ditambah industri perkebunan kelapa sawit kurang dapat meningkatkan taraf kehidupan masyarakat, semakin membuka ruang penentangan.

Sejumlah bentuk-bentuk perjuangan yang dilakukan masyarakat Desa Batu Ampar, terhadap pembangunan perkebunan kelapa sawit di wilayahnya. Mengemukakan, bahwa penentangan terhadap perkebunan industri kelapa sawit tersebut, tidak juga berarti semua masyarakatnya melakukan resistensi, karena beberapa diantaranya menerimanya dengan baik dan ikut berpartisipasi di dalamnya, setidaknya pada tahap permulaan pembukaan perkebunan sawit tersebut.

Hasil sosialisasi saat akan beroperasinya perusahaan perkebunan sawit oleh PT. Fajar Saudara Lestari, pernah diungkapkan bahwa berdirinya perkebunan sawit selain memberikan keuntungan bagi pihak perusahaan, juga memberikan keuntungan bagi pemerintah dan masyarakat setempat. Bagi pemerintah setempat dan pihak perusahaan, bahwa perkebunan sawit manakala dikelola secara baik dapat sebagai bahan bakar nabati, menurut Soekanto (2013:181) sumberdaya energi dapat diperbaharui sebagai alternatif pengganti dari energi fosil, sehingga memberikan kontribusi terhadap pengurangan efek gas buangan emisi serta pendapatan daerah; dan bagi masyarakat merupakan instrumen untuk mengentaskan kemiskinan, meningkatkan taraf hidup dan menyerap tenaga kerja dari masyarakat sekitar, atau banyak masyarakat desa setempat kurang sependapat dengan kedua asumsi tersebut, dan lebih menekankan pada dampak negatifnya, baik bagi keberlangsungan lingkungan maupun masyarakat setempat.

Perihal dampak sosial sehubungan monokultur dalam skala besar Desa Batu Ampar, sebagaimana penelitian di lapangan menunjukkan, bahwa sebanyak 4.487, orang sebagai petani pekebun dan buruh kebun 5.289 dari 14.880 orang penduduk Desa Batu Ampar (sumber kantor camat Batu Ampar tahun 2019) secara langsung maupun tidak langsung terpaksa mengalami pergeseran perekonomian lokal, karena sawit tidak memungkinkan untuk 'tumpang sari' sebagaimana metode yang diandalkan oleh penduduk desa setempat untuk produk seperti tanaman obat, buahbuahan, madu dan lainnya. Akibatnya, setelah kehilangan sumber makanan dan pendapatan tradisionalnya yang tidak dapat menyediakan kebutuhan keluarga sebagaimana halnya belum bisa beralih ke perkebunan sawit berarti menghalangi hak tradisional masyarakat dan adat atas 
tanah.

Kondisi tersebut benar-benar dirasakan masyarakat dikala Perusahaan Perkebunan Sawit PT. Fajar Saudara Lestari tahun 2005 memperoleh lahan seluas \pm 8.000 Ha sekitar 3000 Ha milik masyarakat dengan kompensasi, bahwa bagi anggota masyarakat yang menyerahkan lahan dengan cara perjanjian pola bagi hasil 70:30 setelah masa tanam empat tahun dengan sistem membayar kredit, sedangkan 0,5 Ha lainnya dikonversikan untuk pembangunan infrastruktur seperti jalan, antara lainnya.

Meskipun demikian bahwa berdasarkan penelitian lapangan yang dilakukan di Desa Batu Ampar Kecamatan Batu Ampar, Kabupaten Kubu Raya menunjukkan, bahwa perkembangan industri perkebunan sawit terbilang pesat, bahkan menjadi primadona nilai ekonomiyang cukup tinggi, terutama bagi penduduk lokal setempat. Penduduk lokal memperoleh fasilitasi kebun pola bagi hasil 70:30 untuk kemudian menginspirasikan keinginan untuk mengembangkan usaha perkebunan skala kecil yang dikelola secara pribadi.

Di sisi lain, khususnya perkembangan industri perkebunan kelapa sawit tersebut juga berdampak negatif terhadap penduduk setempat, yakni timbulnya konflik dengan pihak perusahaan perkebunan sawit. Konflik yang terjadi tidak saja disebabkan oleh faktor kesenjangan sosial, ekonomi maupun faktor budaya, tetapi telah meluas pada kesenjangan politik ekonomi, dan harga jual untuk petani penerima pola bagi hasil 70:30 pada tahun 2017 dan 2018 Rp. 270.000 Per KK, kesenjangan komunikasi dan lainnya yang implikasinya cukup merugikan kepentingan pihak perusahaan perkebunan kelapa sawit maupun maupun penduduk setempat.

Selanjutnya pembangunan industri perkebunan kelapa sawit yang terus berkembang disisi lain, disusul terbukanya ruang perlawanan masyarakat lokal akibat dari Perusahaan Perkebunan Sawit PT. Fajar Saudara Lestari yang mengabaikan kepentingan masyarakat atas usaha perawatan sawit yang telah dilakukan, dan diantaranya merubah pola kerjasama yang telah disepakati masyarakat sebelumnya dengan pembagian 70 persen untuk perusahaan dan 30 untuk petani adanya bentuk konflik terungkap adanya faktor kepentingan dan kesenjangan antara petani dan perusahaan dalam pembagian pola kerja sama yang telah disepakati, menginspirasikan keinginan kuat untuk melakukan penelitian tentang: Konflik sosial antara Perusahaan Kepala Sawit PT. Fajar Saudara Lestari dengan masyarakat Desa Batu Ampar Kecamatan Batu Ampar, Kabupaten Kubu Raya.

\section{METODE PENELITIAN}

Jenis penelitian yang digunakan adalah penelitian deskriptif yang bertujuan menjelaskan secara intensif tentang penelitian dimaksud. Jenis penelitian deskriptif ini dilakukan untuk mengetahui dan menganalisis secara sistematis tentang konflik sosial antara 
Pihak Perkebunan Sawit PT. Fajar Saudara Lestari dengan masyarakat Desa Batu Ampar Kecamatan Batu Ampar, Kabupaten Kubu Raya sesuai fakta dilapangan.

Tipe pendekatan penelitian dilakukan secara intensif, mendalam dan mendetail serta komprehensif untuk menggali secara mendalam mengenai masalah penelitian serta tetap mempertahankan keutuhan obyek penelitian (Sanafiah, 2005:22), dan untuk memahami konsep dasar tentang apa yang akan diteliti, peneliti mengamati dan memahami fenomena sosial yang terjadi di lapangan, khususnya berkaitan klaim lahan antara masyarakat Desa dengan Pihak perkebunan Sawit PT. Fajar Saudara Lestari, dengan melakukan pengamatan secara langsung dan mencari informasi sebanyak-banyaknya dari pihak-pihak yang berkompeten.

Penentuan informan dalam penelitian ini dilakukan secara bertujuan (purposive), Adapun pihak-pihak yang dijadikan subjek penelitian (informan) sehubungan penelitian tentang konflik sosial antara Pihak Perkebunan Sawit PT. Fajar Saudara Lestari dengan masyarakat Desa Batu Ampar Kecamatan Batu Ampar, Kabupaten Kubu Raya, antara lain : Warga Desa Batu Ampar yang terlibat konflik sosial terkait klaim lahan dimaksud; Pimpinan Perkebunan Sawit PT. Fajar Saudara Lestari.; Kepala Desa Batu Ampar (Lokasi lahan yang diklaim); Tokoh masyarakat Batu Ampar.

Teknik pengumpulan data mengenai klaim lahan, sehubungan konflik sosial antara Pihak Perkebunan Sawit PT. Fajar
Saudara Lestari dengan masyarakat Desa Batu Ampar Kecamatan Batu Ampar, Kabupaten Kubu Raya, dilakukan dengan teknik Observasi dan Wawancara

Teknik analisis data menurut Sugiyono (2007:89) adalah proses mencari dan menyusun secara sistematis data yang diperoleh dari hasil wawancara, catatan lapangan, dan dokumentasi dengan cara mengorganisasikan data ke dalam kategori, menjabarkan kedalam unit-unit, melakukan sintesa, menyusun kedalam pola, memilih mana yang penting dan yang akan dipelajari, dan membuat kesimpulan sehingga mudah dipahami oleh diri sendiri dan orang lain.

Adapun langkah-langkah dalam menganalisis data (informasi) sehubungan konflik sosial antara Pihak Perkebunan Sawit PT. Fajar Saudara Lestari dengan masyarakat Desa Batu Ampar Kecamatan Batu Ampar, Kabupaten Kubu Raya, adalah Reduksi Data; Data Display (Penyajian Data) ; Conclusion Drawing/Verification. Agar hasil penelitian dapat mencapai tingkat kredibilitas yang tinggi, maka hasil penelitian ini harus dilakukan triangulasi.

\section{HASIL DAN PEMBAHASAN}

\section{Perubahan Struktur Sosial- Ekonomi Tradisional}

Hasil temuan terungkap

pembangunan perkebunan melalui pola bagi hasil telah berlangsung lama ternyata upaya pemerintah kali ini dinilai cukup memberikan hasil, disamping telah merubah struktur masyarakat yang tradisional menuju kemandirian dalam mengelola alam meskipun menjadi 
"pekerja" dilahannya sendiri, membangun akselerasi secara sosialekonomi kepada pemilik modal, dan pada dekade awal pengusahaan pola bagi hasil ini yang didapat masyarakat hanya berupa trickle down effects atau sebagai rembesan saja.

Hanya saja berdasarkan temuan dalam penelitian ini bahwa yang menjadikan penyebab kondisi masyarakat sulit terangkat bahkan dinilai "terpuruk" dari kehidupannya semula tradisional berkisar tentang: (1) Pasifnya (cendrung menunggu) sejumlah kepemimpinan perdesaan di Kecamatan Batu Ampar, dan berujung pada terjadinya urbanisasi dan pekerja sosial ke kota-kota atau ke negara jiran; (2) Pandangan kemunusiaan yang kurang manusiawi terhadap golongan masyarakat miskin, hingga menyebabkan martabat kemanusiaan kaum lemah menjadi semakin terjepit dan terus mempola di dalam konteks kelemahannya; (3) Secara struktural dan integral dinilai belum ada rencana induk pengembangan masyarakat di Kecamatan Batu Ampar secara tepat guna mempertemukan usaha-usaha pemerintah dan kegiatan masyarakat; (4) Struktur dan jenjang pendidikan yang kurang menunjang secara langsung terhadap kecerdasan dan keterampilan serta kesejahteraan masyarakat, sehingga kondisi alam Kecamatan Batu Ampar yang agraris dapat secara leluasa diekploitasi oleh pihak-pihak luar yang syarat kepentingan;

Berdasarkan situasi dan kondisi lapangan penelitian dapat ditelusuri yang mampu dicermati, kemudian melahirkan temuan lainnya dalam rangka menemukan pola masyarakat Kecamatan Batu Ampar yang kini telah mengalami perubahan signifikan sebagaimana harapan, yaitu kemaslahatan kehidupan secara sosial dan ekonomi.

Ditelusuri eksistensi kelompokkelompok masyarakat di Kecamatan Batu Ampar ini dinilai belum sepenuhnya mendapatkan bimbingan dan arahan secara jelas dari pihak-pihak Pemerintah Kabupaten Kubu Raya. Padahal perhatian pemerintah daerah setempat dari jalinan bimbingan dan arahan secara kontinyuitas dinilai justru memberikan manfaat yang cukup besar agar segenap masyarakat yang tersegmentasi pada kelompok-kelompok tersebut tidak mengalami kejenuhan di dalam kondisi masyarakatnya sendiri yang cenderung monoton, hingga berdasarkan keterangan para informan dinilai sebagai kondisi yang penuh dengan ketidakpastian. Akibatnya masyarakat tidak mendapatkan apa-apa karena rugi akibat salah perhitungan pada waktu memborong pekerjaan atau mengalami hambatan dan kendala sehingga target pekerjaan menjadi lebih lama dari waktu yang direncanakan

Hasil temuan ungkapan informan kelompok sosial masyarakat yang perlu mendapatkan perhatian secara serius ini sebagaimana konsep Suharto (2005:7) dalam artikelnya yang berjudul "konsep dan strategi pengentasan kemiskinan menurut perspektif pekerja sosial" membagi 3 (tiga) kriteria/katagori kemiskinan, yaitu: (1) Kelompok miskin yang paling miskin (destitute) atau yang 
sering didefenisikan sebagai fakir miskin; (2) Kelompok Miskin (poor). Kelompok ini memiliki pendapatan dibawah garis kemiskinan, namun secara relatif memiliki akses terhadap pelayanan sosial dasar, misalnya masih memiliki sumbersumber financial, memiliki pendidikan dasar atau tidak buta huruf; (3) Kelompok rentan (vulnerable group). Kelompok ini bebas dari garis kemiskinan. Kelompok ini sering disebut "near poor" atau agak miskin. Memiliki kehidupan relatif lebih baik dibanding destitute atau miskin, yang sebenarnya masih rentan terhadap berbagai perubahan sosial.

Selanjutnya ungkapan informan berdasarkan tinjauan historis mengenai realitas kondisi di Kecamatan Batu Ampar telah mempola karakter tertentu untuk memperjelas bahwa para pemimpin perdesaan di Kecamatan tersebut, baik formal maupun non formal umumnya terdiri dari orang-orang yang dipandang paling kuat - memiliki kelebihan tertentu - serta berkecukupan, hingga menjadikan pemimpin tersebut kurang peka terhadap gejolak sosial yang berkembang pada lingkungan masyarakat dimana ia berada. Padahal sebagaimana diketahui bahwa masyarakat perdesaan sebagai penghuni di Kecamatan Batu Ampar, sebelumnya memang sudah memiliki pandangan kritis, disamping sikapnya yang "nrimo" terhadap segenap permasalahan baik secara internal maupun eksternal. Sikap-sikap inilah dapat dinilai sebagai benih-benih perubahan sosial-ekonomi masyarakat.

Hal lain sebagai indikator lemahnya produktivitas masyarakat tradisional di Kecamatan Batu Ampar yang dimaksudkan bukan karena kekurangan tenaga pendidikan. Akan tetapi terletak pada cara dan isi yang diberikan di dalam institusi pendidikan yang ada, dan dapat secara mudah diterapkan serta digunakan dalam mengubah perilaku sosial, khususnya perilaku ekonomi masyarakat.

Mengingat, kualitas intelektual akan menciptakan manusia-manusia cerdas dan terampil dalam bekerja sama melalui proses sosialisasi demi kepentingan bersama, menuju pemberdayaan masyarakat perdesaan. Karena realitas belum sejalan dengan harapan, akibatnya terhadap lulusan yang ada di Kecamatan Batu Ampar cenderung untuk bersikap ambivalensi atau mendua, dengan ragu menentukan sikap apakah akan membangun lingkungan sebagai tempat tinggal, atau meninggalkan wilayah kelahirannya. Oleh karena itu, dalam konteks pembangunan kewilayahan dinilai menjadi kesepian atas tenaga-tenaga muda yang segar dan semestinya dapat menjadi tenaga penggerak, perintis serta pembangun, sekaligus menciptakan kepemimpinan formal maupun non formal yang berkualitas.

Ditelusuri pola kehidupan masyarakat Kecamatan Batu Ampar yang berstruktur secara komunal dan homogen ini, jika disimak secara cermat dinilai tidak jauh berbeda dengan kondisi di daerah-daerah lain kawasan pedalaman Kalimantan Barat, karena selain diantara masyarakatnya yang saling mengenal 
juga memiliki kedekatan hubungan yang lebih intim, meskipun terhadap hubungan tersebut tersimpan nilai-nilai hegemony bahkan dominasi demi pencapaian orientasi kepentingan kelompok masyarakat satu kepada kelompok masyarakat lainnya, terutama dalam hal penguasaan sumberdaya bahkan kekuasaan.

\section{Struktur Kelompok-Kelompok Masyarakat Atas Potensi Sumberdaya Alam}

Hasil temuan ungkapan informan kehidupan sosial di Kecamatan Batu Ampar yang telah mempola hingga melahirkan kelompok-kelompok masyarakat yang berstruktur, tidaklah terlepas dari berbagai bentuk perjuangan demi meraih segenap potensi dalam pencapaian keleluasaan secara ekonomi dan kedudukan. Atas dasar itu, di Kecamatan Batu Ampar sebagaimana penelitian ini dalam perkembangan kemudian terbentuk menjadi 3 (tiga) kelompok, yaitu: (a) Kelompok akuasi, yaitu pihak perusahaan; (b) Kelompok kepentingan, yaitu kelompok tim 20; dan (c) Kelompok terorganisir, adalah petani / masyarakat pemilik lahan yang mengalami kekecewaan.

Ditelusuri ketiga kelompok tersebut kemudian melakukan aktivitas perjuangan atas segenap sumberdaya di Kecamatan ini dinilai sebagai konsekuensi dari adanya kepentingan sebagai kompensasi dari relasi-relasi sosial. Kepentingan yang paling substansial di Kecamatan Batu Ampar berkisar tentang kekuasaan dan ekonomi, hingga menjurus pada upaya-upaya penciptaan ketergantungan secara penuh dari kelompok yang lemah terhadap kelompok kuat. Meskipun diketahui, sebagaimana ditegaskan Forse bahwa hubungan sosial merupakan sumber daya, mengingat sumber-sumber daya yang dikuasai merupakan rekomendasi dalam merealisasikan tujuan, baik secara individual maupun kelompok.

Sebagai bukti dan alasan mendasar bahwa hampir seluruh paranata di setiap Desa pada tingkat Kecamatan Batu Ampar dinilai memiliki ciri yang sama yakni dibentuk dari atas, atas dasar legitimasi pejabat-pejabat publik yang berwenang.

Selanjutnya terungkap bahwa posisi masyarakat bawah pada dasarnya dinilai sebagai peluang menutup segenap kesempatan karena terbatasnya SDM. Akibatnya, kesempatan dan saluran untuk mengaktualisasikan aspirasi, membuat masyarakat bawah di Kecamatan ini tidak terbiasa untuk mengajukan pandangannya dan memberikan penilaian terhadap sesuatu hal, belum lagi diskriminasi dalam akses pendidikan menjadi faktor antara yang memperparah kondisi ini.

Guna menjawab problematika ini, pada prinsipnya segenap stakeholder Kecamatan dan Desa meski berupaya mengembangkan skema akselerasi kepentingan sebagai format dasar yang mesti dikembangkan, dimana segenap pilar-pilar Kecamatan dan Desa yang konon identik sebagai alat kekuasaan digeser kearah fasilitator dengan meninggalkan sedikit demi sedikit 
perannya sebagai regulator. Dengan demikian segala instrumen yang dikembangkan yang selama ini terus mendegradasikan masyarakat bawah kepada bentuk-bentuk formalisme akan pudar sebagai wujud nyata dari itikad untuk membangun demokrasi di tingkat bawah.

\section{Pergeseran Masyarakat Batu Ampar}

Perubahan sistem perkebunan kadang-kadang menimbulkan kesulitan bagi jadwal kegiatan masyarakat tradisional. Bagi masyarakat tradisional kegiatan perkebunan dilakukan bersamaan dengan sejumlah kegiatan produksi yang lain, seperti memburuh para petani. Mereka sangat aktif mengatur jadwal dalam kesehariannya, sehingga semuanya bisa berjalan. Jika sistem perkebunan mengalami perubahan maka seluruh jadwal kegiatan dan komitmen kepada pihak-pihak lain juga akan mengalami perubahan. Besar kemungkinan bahwa kegiatan-kegiatan tambahan tersebut terpaksa harus ditinggalkan apabila sistem perkebunan yang diterapkan menghendaki pengolahan secara intensif. Bagi masyarakat tradisional, rusaknya hubungan karena tidak terpenuhinya janji-janji bisa berakibat serius, karena komitmen-komitmen itu merupakan back upsystem bagi masyarakat, seandainya usaha-usaha pokoknya mengalami kegagalan seperti panen dimusnahkan hama, perubahan cuaca secara drastis dan sebagainya.

\section{Ungkapan} informan pembangunan perkebunan skala besar yang melibatkan masyarakat, masalah biasa timbul karena dasar pencariannya sebagai peladang berpindah yang tadinya mempunyai pola hubungan yang bebas terhadap lahan, yaitu hutan dan tanah, kini menjadi pekebun yang terikat sistem dan syarat serta aturan-aturan yang baru. Sebenarnya keterikatan terhadap aturanaturan yang terasa asing oleh petani inilah yang kadang-kadang menjadi sebab dari penolakannya terhadap perkebunan dalam skala besar. Akan tetapi hal tersebut dapat dinilai sebagai dorongan untuk mencapai keberhasilan sebagai motif yang penting sekali. Melihat kesuksesan masyarakat sendiri membuka wawasan berpikir dan mendorong motivasi untuk berusaha lebih keras lagi.

\section{Dinamika Perubahan Sosial Ekonomi Masyarakat Melalui Pola Perkebunan Sawit}

Hasil temuan berdasarkan pengamatan dilapangan di lapangan penelitian menemukan makna berupa tujuan dari realisasi pembangunan pola bagi hasil tersebut, tujuan itu mencakup: (1) Aspek ekonomi, yaitu menumbuhkan dan meningkatkan produktifitas di Kecamatan Batu Ampar, khususnya dalam rangka memerangi tingkat kemiskinan masyarakat melalui beroperasinya PT. Fajar Saudara Lestari yang pengelolaan Perkebunan Kelapa Sawit bersifat Bagi hasil; (2) Aspek sosial, yaitu mengarah pada pemerataan hasil-hasil pembangunan untuk kesejahteraan penduduk; dan (3) Aspek kultural, berupa upaya peningkatan kualitas hidup. 
Upaya mempengaruhi terjadinya perubahan-perubahan sosial dan tranfer ilmu pengetahuan dan teknologi kepada masyarakat di Kecamatan Batu Ampar, utamanya bagi hasil sawit, terdapat kecenderungan perubahan-perubahan itu dipercayakan kepada sistem birokrasi. Dalam hal ini, baik oleh birokrasi pemerintah sebagai fasilitator maupun birokrasi swasta melalui mekanisme kerja PT. Fajar Saudara Lestari sebagai lembaga yang bertanggung jawab atas keberhasilan produktivitas bagi hasil. Namun, apapun alasannya bahwa pembangunan bagi hasil maupun inti pada substansinya itu dibiayai oleh masyarakat, terutama melalui penyerahan lahan dan pengerjaannya, bahkan melalui pajak. Oleh karena itu ada legitimasi bahwa manajemen pembangunan harus ditentukan oleh kekuasaan yang berada di atasnya. Peranan pemerintah atau pihak swasta di atasnya yang dominan seperti ini mengakibatkan proses pembangunan pola bagi hasil berjalan mengikuti saluran dari atas ke bawah top down strategy. Kebijaksanaan ini dapat diamati dalam pelaksanaan kegiatan di Kecamatan Batu Ampar yang pada umumnya merupakan realisasi dari program nasional.

Hasil penelitian dan temuan terhadap pola bagi hasil di Kecamatan Batu Ampar ini, sebagaimana diketahui setidaknya telah mengetengahkan dua paradigma pembangunan yang sudah umum dibahas oleh kalangan ahli pembangunan, yaitu: (1) Production centered development approach yang orientasinya mengutamakan peningkatan produksi dan pertumbuhan; dan (2)
People centered development approach yaitu model pembangunan yang bertumpu pada kekuatan masyarakat atau komunitas. Hanya saja, menurut Tjokrowinoto (1986:109) terhadap penerapan yang mengadopsi pelaksanaan pembangunan yang mengutamakan peningkatan dan pertumbuhan produksi saja ternyata menunjukkan ketimpangan yang memprihatinkan. Artinya, penerapan strategi pembangunan yang menekankan pada peningkatan produksi dan pertumbuhan, sepanjang yang bisa diamati memberikan pengamatan semakin kuatnya dominasi perusahaan dan pemerintah, dan kedepan dikhawatirkan terhadap masyarakat yang terlibat tersebut tidak tertarik lagi untuk memprakarsai dan melakukan usahausaha dalam rangka memperbaiki kondisi hidup karena timbul sikap apatisme. Artinya, terhadap strategi pembangunan pola bagi hasil seperti ini pada hakekatnya juga menempatkan masyarakat sebagai obyek bantuan dan berbagai pelayanan pemberian fasilitas sosial. Implikasinya, kemampuan masyarakat menurun dan tidak mampu mengembangkan inisiatif lokal dalam hal pengelolaan bagi hasil, apalagi memecahkan sendiri masalah-masalah yang dihadapinya.

Strategi lainnya, yaitu berkenaan dengan penerapan model pendekatan people centered development approach, yaitu berupa model pembangunan yang bertumpu pada kekuatan masyarakat atau masyarakat sangat menekankan pentingnya nilai-nilai prakarsa lokal dan spesifikasi sumber daya pada komunitas. 
Peranan yang diletakkan pada individu atau masyarakat bukanlah sebagai obyek melainkan sebagai subyek atau pelaku yang menentukan tujuan, mengawasi sumberdaya dan mengarahkan proses yang mempengaruhi hidupnya.

Pendekatan pengelolaan seluruh potensi dan sumber daya yang bertumpu pada komunitas tidak harus sepenuhnya berorientasi pada kebijaksanaan pemerintah, program-program serta proyek-proyek yang dirancang. Namun, pemanfaatan sumber daya hendaknya berpijak pada kebutuhan, kemampuan dan penguasaan atas sumber daya produktif dalam rangka kepentingan masyarakat. Prinsip yang dianutnya bahwa peluang dan kesempatan untuk berperan secara efektif dalam kegiatan pembangunan harus diberikan kepada masyarakat yang akan menanggung akibat dari praktek pembangunan tersebut.

Bertolak dari hasil penelitian mengenai peningkatan kapasitas masyarakat dalam rangka pembangunan kualitas manusia yang telah direalisasikan oleh PT. Fajar Saudara Lestari oleh peneliti mencoba mengadaptasikannya terhadap bentuk penumbuhan kemandirian masyarakat melalui serangkaian pola bagi hasil 70 ; 30 netto. Program ini mencakup serangkaian kegiatan membangkitkan usaha perkebunan masyarakat melalui pola bagi hasil 70 ; 30 netto sebagai upaya menemukan alternatif terbaik bagi peningkatan taraf hidup masyarakat setempat.

Keterlibatan masyarakat dalam pola bagi hasil 70 ; 30 netto dinilai sebagai bentuk kemandirian masyarakat, karena memiliki kemampuan dalam mengakselerasikan kemampuan dengan memanfaatkan sumber daya manusiawi dan sumber daya alami dalam rangka mencapai kehidupan masyarakat yang lebih baik secara mandiri. Artinya, dukungan bantuan teknis dari pihak luar pihak PT. Fajar Saudara Lestari harus diberi nilai sebagai stimulans yang bersifat sementara dan berada dalam jangkauan masyarakat untuk mengenali dan mendapatkannya. Oleh karena itu, sinergisitas pola bagi hasil $70 ; 30$ netto khususnya pola bagi hasil $70 ; 30$ netto harus tetap dirumuskan menjadi strategi yang berorientasi pada dua hal pokok, yaitu: (1) Pembangunan pola bagi hasil $70 ; 30$ netto perlu terus didukung oleh pengenalan teknologi mulai dari yang sederhana sampai kepada yang lebih canggih; dan (2) Pembangunan pola bagi hasil $70 ; 30$ netto harus tetap diorientasikan kepada kepentingan masyarakat dengan bertumpu pada potensi masyarakat.

Hasil penelitian ini setidaknya menunjukkan bahwa berkenaan dengan pembangunan pola bagi hasil $70 ; 30$ netto telah mencakup empat unsur pokok sebagai penciptaan kemandirian masyarakat di Kecamatan Batu Ampar, yaitu: (1) Menempatkan masyarakat sebagai individu atau kelompok sebagai subyek dan obyek; (2) Masyarakat merasa pemberian bimbingan dan penyuluhan yang dilakukan oleh PT. Fajar Saudara Lestari sebagai alih ilmu pengetahuan dan penerapan teknologi 
dalam upaya pengembangan bagi hasil; (3) Penyedia stimulan bersifat teknis dan kebendaan; dan (4) Terjadi peningkatan keterampilan dan produktivitas. Penciptaan kemandirin sejalan dengan teori yang dikembangkan Rostow tentang syarat utama mencapai tingkat masyarakat modern, yaitu berkenaan dengan tersediaan modal, dan Teori Chenery tentang peranan penting pembentukan modal (Fakih, 2002:56-54) sebagai fenomena yang dapat menjadi pembuktian. Artinya, masyarakat disini sangat membutuhkan tambahan modal kerja untuk meningkatkan omzet maupun dipersifikasi usahanya, khususnya dalam hal pengelolaan bagi hasil yang secara legalitas telah menjadi bagian dari kehidupan sosial-ekonominya.

\section{Konflik Lahan Antara Perusahaan Dengan Petani Sawit}

Salah satu faktor pemicu terjadinya konflik antara masyarakat Desa Batu Ampar dengan pihak PT. Fajar Saudara Lestari didasari inspirasi, bahwa masyarakat selaku petani tetap merasa menjadi 'buruh' di tanahnya sendiri. Maknanya bahwa masyarakat menilai bahwa hadirnya perusahaan perkebunan sawit tersebut tidak memberikan aspek pencerahan bagi kehidupan yang lebih baik.

PT. Fajar Saudara Lestari telah membangun kerjasama dengan masyarakat Desa Batu Ampar dengan pembagian pola bagi9 hasil $70 ; 30$ netto, 70 persen untuk perusahaan dan 30 persen untuk petani, Kondisi demikian dianggap masyarakat sebagai bentuk perlakuan yang tidak menghargai eksistensi masyarakat lokal terutama dalam bentuk materi, bahkan berkembang menjadi bisnis tanah sebagaimana dipraktikkan perusahaan perkebunan tersebut. Ironisnya bahwa perusahaan belum memberikan hasil sesuai yang di janjikan pada sat sosialosasi kepada masyarakat Desa Batu Ampar sebagai petani penerima pola bagi hasil $70 ; 30$ netto. Akibatnya, masyarakat sering melakukan aksi untuk menarik kembali lahannya. Pada bulan Mei 2018 masyarakat Desa Batu Ampar dua kali melakukan aksi aksi dan melakukan penutupan pabrik kelapa sawit milik PT Fajar Saudarfa Lestari dan melakukan aksi penutupan kantor koperasi usaha produsen karya bersama selaku mitra perusahaan untuk membagi uang kepada petani penerima pola bagi hasil $70 ; 30$ netto.

Ditelusuri konflik sosial semakin menghangat dan tuntutan masyarakat agar tanah yang telah di serahkan segera di kembalikan kepada petani karena sangat diperlukan untuk kebutuhan pangan masyarakat terus digelar yang kegiatan masyarakat ini bersifat fluktuatif. Masyarakat Desa Batu Ampar menilai bahwa Pihak Perusahaan Perkebunan Sawit PT. Fajar Saudara Lestari tidak serius mengembangkan perkebunan, dan justru menciptakan kemiskinan masyarakat.

Berdasarkan kronologis yang dipaparkan tersebut, dapatlah dimaknai, bahwa terdapat beberapa faktor yang menjadi penyebab konflik sosial antara Pihak Perusahaan Perkebunan Sawit PT. Fajar Saudara Lestari dengan masyarakat 
Desa Batu Ampar, sebagaimana Gambar 2 berikut:

Gambar 2. Faktor-Faktor Penyebab Konflik Antara Perusahaan Perkebunan Sawit Pt. Fajar Saudara Lestari Dengan Masyarakat Desa Batu Ampar

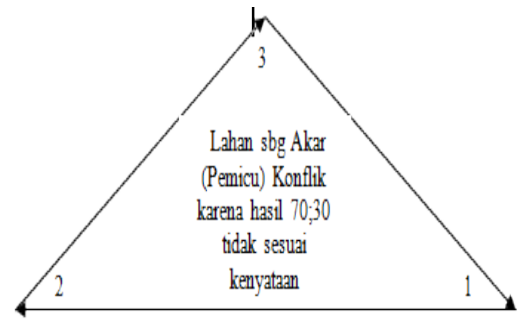

Sumber: Hasil Olahan Peneliti, Tahun 2019.

Berdasarkan Gambar 2 tersebut dapat dijelaskan bahwa lahan masyarakat antara Perusahaan Perkebunan Sawit PT. Fajar Saudara Lestari kepada Perusahaan Perkebunan Sawit PT. Fajar Saudara Lestari (tahun 2008), sebagai akar (pemicu) konflik sosial perebutan lahan antara masyarakat Desa Batu Ampar dengan PT. Fajar Saudara Lestari. Pola Bagi Hasil $70 ; 30$ Netto tersebut dinilai sebagai pemicu konflik, karena terindikasi ada unsur kapitalis yang menguntungkan atas pemilik kebun kelapa sawit atas lahan masyarakat dengan 'dalih' Tampa perlu bekerja masyarakat Desa Batu Ampar mendapatkan konpensasi setiap bulan nya dari Perusahaan Kelapa Sawit PT.Fajar Saudara Lestari.

Terungkap kapitalisasi lahan semakin menjadi karena terindikasi oleh 3 (tiga) keuntungan yang diperoleh Perusahaan Perkebunan Sawit PT. Fajar Saudara Lestari, meliputi: (1) Dengan pola bagi hasil 70 ; 30 netto Pihak Perusahaan Kurang terbuka kepada petani penerima bagi hasil 70 ; 30 netto; (2) Janji janji perusahaan pada saat sosialiasi kepada masyarakat Desa Batu Ampar tidak sesuai kenyataan; dan (3) Eksistensi perusahaan mendapat dukungan aparatur pemerintah setempat, sedangkan kepentingan hidup masyarakat setempat cendrung terabaikan.

Berdasarkan faktor-faktor penyebab konflik sosial antara Pihak Perusahaan Perkebunan Sawit PT. Fajar Saudara Lestari dengan masyarakat Desa Batu Ampar tersebut, dapat dikemukakan sebagai akibat dari tidak dioptimalkan peran masyarakat, tetapi justru dikerdilkan dalam sistem yang dibangun perusahaan hingga masyarakat melakukan perlawanan. Kasus yang terjadi ini sangat disayangkan bahwa aparatur justru secara langsung menjadi bagian dari pendukung sistem ini, hingga sulit menunjukkan keberpihakannya pada petani.

Masyarakat Desa Batu Ampar yang melakukan pengaduan kepada pemerintah, terkesan diselesaikan "setengah hati" atau dengan jalan tengah. Jalan tengah penyelesaian konflik sosial ini menjadi tidak lagi produktif untuk diambil pemerintah. Keputusan dan regulasi yang tegas adalah justru menggantikan sistem perkebunan yang bertumpu pada perusahaan dengan menjadikan masyarakat sebagai tumpuan alternatif dalam perkebunan sawit.

Penyelesaian sengketa atas timbulnya saling klaim lahan berikut penyebab terjadinya tindakan penyegelan 
pabrik kelapa sawit dan kantor koperasi produsen usaha karya bersama yang dilakukan oleh masyarakat sebagai pelaku, dikarenakan ketidakpuasan pelaku atas ketidakjelasan perusahaan, serta rasa lelah dan merasa aspirasi yang disampaikan tidak didengar dan tidak dipedulikan oleh pihak perusahaan tersebut, ditambah faktor provokasi dari orang-orang tertentu, pemaksaan kehendak, komunikasi yang tidak sepaham, dan kepentingan tertentu. Upaya-upaya yang dilakukan oleh penegak hukum untuk menanggulangi penyegelan yang dilakukan oleh masyarakat, adalah memberikan penyuluhan kepada masyarakat tentang penyampaian aspirasi yang baik dan benar sesuai Undang-undang Nomor 9 Tahun 1998 tentang Kebebasan Menyampaikan Pendapat di Muka Umum,

Ungkapan informan perihal konflik klaim lahan antara masyarakat Desa Batu Ampar dengan Pihak Perusaahaan Perkebunan Sawit PT. Fajar Saudara Lestari sebagaimana versi MUSPIKA Kecamatan Batu Ampar, bahwa pihaknya sudah melakukan pemanggilan kepada pihak managemen PT. Fajar Saudara Lestari. Terutama tentang upaya penyelesaian kasus penyegelan parbrik kelapa sawit dan penyegelan kantor koperasi produsen usaha karya bersama.

Kapolsek Batu Ampar telah melakukan akomodasi untuk fasilitas mediasi antara warga Desa Batu Ampar dengan pihak PT. Fajar Saudara Lestari di aula Polsek Batu Ampar. Hematnya kemudian bahwa pihaknya sedang crosscheck data antara yang disampaikan oleh masyarakat, yakni pihak PT. Fajar Saudara Lestari melakukan penggelapan dana bagi hasil pola 70;30 Dengan keterangan dari pihak perusahaan yang melakukan pengelolaan lahan tersebut, akan ditemui kebenaran tentang laporan masyarakat tersebut.

Bupati Kubu Rayakala itu mengungkapkan, bahwa TP5K Kabupaten Kubu Raya telah mengambil langkah penyelesaian kasus tersebut. Pihaknya juga berjanji akan memberikan teguran keras kepada pihak perusahaan, manakala memang yang dilaporkan masyarakat tersebut adalah benar, terlebih mengolah lahan dari masyarakat dan melakukan penggelapan dana pola bagi hasil 70;30 netto. Sebagaimana dikemukakannya, bahwa jika perusahaan melanggar perjanjian, berarti terjadi pelanggaran aturan yang ada dan harus diberikan sanksi.

Pernyataan Bupati Kubu Raya dapat ditelusuri pada Januari 2019 lalu, sebagaimana fakta di lapangan menunjukkan, kemudian terjadi penolakan atas pernyataan tersebut, terkait sengketa lahan perkebunan kelapa sawit di Kecamatan Batu Ampar. Saat itu Pemerintah Kabupaten Kubu Raya menfasilitasi pertemuan antara Pihak Perusahaan Perkebunan Sawit PT. Fajar Saudara Lestari dengan pihak petani setempat.

Pada pertemuan tersebut sebagaimana versi masyarakat justru menjelaskan sebaliknya, bahwa mayoritas petani menginginkan lahannya 
ditarik dari perkebunan PT. Fajar Saudara Lestari, Meskipun tidak dapat dipungkiri, bahwa masih ada petani yang pro kepada PT. Fajar Saudara Lestari, tetapi jumlahnya pun terbilang sedikit.

Persoalannya adalah bermula ketika mayoritas warga yang bermitra dengan PT. Fajar Saudara Lestari merasa dirugikan. Berdasarkan perjanjian yang diperkuat dengan berita acara lanjutan antara PT. Fajar Saudara Lestari dengan masyarakat-Desa Batu Ampar bahwa semua lahan dibangun kebun yang hasilnya petani penerim bagi hasil mendapt 30 dan 70 untuk perusahaan Pada perkembangan selanjutnya, masyarakat yang menerima pembagian kebun bagi hasil tidak sesuai dengan apa yang di harapkan dan apa yang di sampaikan pada saat sosialiasi pembukan kebun pada tahun 2005 sehingga petani mulai pertama kali menerima pola bagi hasil sebesar Rp 50.000,- dan pada tahun 2020 menerima sebesar Rp. 270.000,- .

Upaya penyelesaian konflik telah dilakukan, diantaranya oleh Muspika Kecamatan Batu Ampar dan Bupati Kubu Raya dengan menawarkan dua opsi. Opsi pertama bahwa kerjasama tetap dilanjutkan dengan pembagian hasil 70 persen untuk perusahaan dan 30 persen untuk masyarakat. Opsi kedua bahwa lahan milik masyarakat dikembalikan dengan syarat mengganti kerugian perusahaan sebesar yang telah di keluarkan oleh perusahaan membangun kebun sawit. Opsi pertama mendapat penolakan dan ada yang menerima masyarakat selaku pemilik lahan yang mana perusahaan harus terbuka kepada petani penerima pola bagi hasil, sedangkan opsi kedua dapat diterima dengan catatan masyarakat selaku pemilik lahan dapat melihat langsung kwitansi bukti pembangunan lahan dari PT Fajar Saudara Lestari.

\section{SIMPULAN DAN REKOMENDASI}

\subsection{Simpulan}

Berdasarkan uraian yang telah dijelaskan sebelumnya, dapat ditarik kesimpulan bahwa hasil penelitian mengenai "Konflik Sosial antara Perusahaan Perkebunan Sawit PT. Fajar Saudara Lestari dengan Masyarakat Kecamatan Batu Ampar, Kabupaten Kubu Raya," disimpulkan berikut:

\subsubsection{Konflik sosial antara Perusahaan} Perkebunan Sawit PT. Fajar Saudara Lestari dengan masyarakat, disebabkan perubahan struktur sosial ekonomi masyarakat dari sistem kapasitas melalui pola kemitraan bagi usaha. Akibat masuknya perusahaan perkebunan sawit, terjadi pengelompokan masyarakat atas struktur sumber daya, meliputi: kelompok yang memiliki kekuasaan sumberdaya ekonomi dan kelompok yang memiliki sumberdaya sosial. Pengelolaan perkebunan sawit yang bergerak jauh dari upaya mensejahterakan masyarakat, melahirkan konflik terbuka perebutan lahan yang mengabaikan kepentingan masyarakat setempat.

4.1.2. Proses konflik sosial antara Perusahaan Perkebunan Sawit PT. Fajar 
Saudara Lestari dengan masyarakat Desa Batu Ampar, bermula tahun 2010 bahwa masyarakat yang menyerahkan lahan akan mendapatkan bagi hasil netto 70;30 setelah masa tanam 48 bulan dengan. Tahun 2011 sebagaian masyarakat Desa Batu Ampar menjual lahan yang telah di bangun kebun sawit oleh PT. Fajar Saudara Lestari ke pengusaha bernama RS. Terjadinya proyek pemerintah di lahan yang telah di bangun kebun kelapa sawit oleh PT. Fajar Saudara Lestari tahun 2011, Perebutan lahan oleh kelompok WWN tahun 2012, pada tahun 2018 penyegelan pabrik kelapa sawit PT Fajar Saudara Lestari dan tahun 2019 penyegelan kantor Koperasi Produsen Usaha Karya Bersama merupakan klimiks konflik sosial hingga masyarakat yang merasa haknya telah dirampas pihak perusahaan

4.2. Rekomendasi.

Berdasarkan kesimpulan penelitian mengenai "Konflik Sosial antara Perusahaan Perkebunan Sawit PT. Fajar Saudara Lestari Kecamatan Batu Ampar, Kabupaten Kubu Raya," maka disarankan:

4.2.1. Perubahan struktur ekonomi soaial dan pola-pola kebijakan yang tidak sesuai dengan keadaan masyarakat akan menyebabkab terjadinya konflik, tak terkecuali akibat masuknya Perusahaan Perkebunan Sawit di Kecamatan Batu Ampar, Kabupaten Kubu Raya. Agar tidak terjadi konflik antara masyarakat dengan pihak perusahaan maka pemerintah setempat disarankan benar-benar memperhatikan aspek pembagian hasil usaha tani yang kerap kali menyebabkan perubahan pada berbagai aspek kehidupan masyarakat.

4.2.2. direkomendasikan dalam pengembangan sumberdaya alam harus memperhatikan berbagai aspek kehidupan, seperti: peningkatan kemakmuran dan kesejahteraan ekonomi masyarakat, memperhatikan kelangsungan ekologi, serta menghargai sistem sosial budaya daerah setempat, sehingga akan meminimalisasi potensi konflik yang terjadi atas pengembangan perkebunan sawit.

\section{Referensi}

Angi, E. dan Catur, BW, (2001)., Praktek Pengelolaan Hutan Masyarakat Secara Tradisional di Kalimantan Timur.Majalah Kehutanan Indonesia Edisi II September 2001. Jakarta: Departemen Kehutanan.

Bee, R L. (1974). Patterns and Processes. London: Collier Macmillan Publishers.

Beilharz, P. (2003)., Teori-Teori Sosial. Observasi Kritis Terhadap Para Filosof Terkemuka. Yogyakarta: Pustaka Pelajar.

Borras, S., M. Jr., RHl, Ian, S \& Ben, W, and Wendy, W. (2011). Towards a Better Understanding of Global Land Grabbing: An Editorial.

Dahrendorf, R.( 1959). Class and Class Conflict in Industrial Society. Stanford: Stanford University Press.

Fakih, M. (2002). Runtuhnya Teori Pembangunan dan Globalisasi. Jogjakarta: Pustaka Pelajar.

Gidden, A.,Daniel,Bl, Forse, M.1, at all. ( 2004). Sosiologi. Sejarah dan 
Berbagai Pemikirannya. Editor: Cabin Philippe dan Dortier Francois Jean. Yogyakarta: KreasiWacana.

Hadi, S. (2004). Metodologi Research. Yogyakarta: Andi.

Hall, D., Philip, H., and Tania, M.L. (2011).Powers of Exclusion: Land Dilemmas in Southeast Asia. Singapore: National University of Singapore.

Honour T.F dan Mainwaring R.M. (1988).Sosiologi dan Bisnis. Jakarta: BinaAksara.

Kinloch C. G. (2009). Perkembangandan Paradigma Utama Teori Sosiologi. Cetakan II, bulan Januari. Bandung: CV. PustakaSetia.

Kortens, D. C dan Rudi, K., Eds. (1984). People Centered Development. West Hartford: Kumarian Press.

Miles dan BM, Huberman. (2002). Analisis Data Kualitatif. Bandung: Bina Risda Karya.

Mubyarto, S., Kartodirdjo. (1988). Pembangunan Pedesaan Di Indonesia. Yogyakarta: Liberty.

Nawawi, H.. (2007). Metode Penelitian Bidang Sosial. Yogyakarta: Gadjah Mada University Press.

Ndraha, T. (2007). Pembangunan Masyarakat. Jakarta: Bina Aksara.

Putra, N. ( 2009). Pemikiran Sujatmoko Tentang Jakarta:Gramedia Utama.

Ritzer, G.G. (2004). Teori Sosiologi Modern. Jakarta: Prenada Media.

Ritzer, G. (2013). Sosiologi Ilmu Pengetahuan Berparadigma Ganda. Cetakan Ke-10, bulan Maret. Jakarta: PT. Raja Grafindo Persada. Modern. Jakarta: Kencana Prenadamedia Group

Sanafiah, F. (2005). Penelitian Kualitatif: Dasar-dasar dan Aplikasi. Jakarta:
Rajawali Press.

Soekanto, S. (2013). Sosiologi Suatu Pengantar. Cetakanke 5. Jakarta Rajawali. (2013). Hukum Adat Indonesia .Cetakan Ke-13, bulan Juni. Jakarta: PT. Raja Grafindo Persada.

Sugiyono. (2007). Memahami Penelitian Kualitatif. Bandung: Alfabeta.

Suryabrata, S. (1995). Metodologi Penelitian. Jakarta: PT. Raja Grafindo Persada.

Susan, N. (2009). Pengantar Sosiologi Konflik dan Isu-Isu Konflik Kotemporer. Jakarta: KencanaPrenada Media Group. . (2009). Sosiologi Konflik Dan Isu-Isu Kontenporer. Jakarta: Prenada Media Group.

Sztompka, P. (2004). Sosiologi Perubahan Sosial. Jakarta: Prenada.

Tjokrowinoto, M. (1986). Alternatif Perencanaan Sosial Budaya dalam Sudjatmoko, et al, Masalah Sosial Budaya Tahun 2000. Yogyakarta: Tiara Wacana.

Turner, J. (1978). From Utopia to Where? A Strategy for Reformulating the Dahrendorf Conflict Model.Social Forces.

Wallace \& Wolf. (1995). Reading in Contemporary Socio Logical Theory From Modernity To PostModernity. New Jersey: Prentice Hall

Wirawan. (2010). Konflik dan Manajemen Konflik. Teori, Aplikasi, dan Penelitian. Jakarta: Salemba.

\section{Data, Publikasidan Internet:}

Masrani. (2013). Tesis: Sengketa Tanah Perkebunan PT. Munteq Waniq Jaya Perkasa dengan Masyarakat Kampung Muara Tae Kecamatan Jempang Kabupaten Kutai Barat 
Provinsi Kalimantan Timur. Pada

Program Studi Ilmu Hukum Konsetrasi Agraria.Pdf.

Profil Kecamatan Batu Ampar, Kabupaten Batu Ampar, Tahun 2019. Diakses di Desa Batu Ampar, tanggal 20 Januari 2020.

Suharto, E.di. (2005). Konsep dan Strategi Pengentasan Kemiskinan menurut Prespektif Pekerja Sosial. www.policy.hu. Diakses di Pontianak, 21 Januari 2020. Pukul 09.30 WIB.

PeraturanPerundang-undangan:

Undang-undang Nomor 5 Tahun 1960 Tentang Peraturan Dasar-dasar Pokok Agraria (UUPA).

Peraturan Pemerintah Republik Indonesia Nomor 72 Tahun 2005 tentang Desa. 